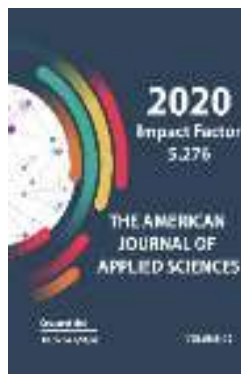

\title{
Testing Is A Responsible Stage Of Geological Forecasting, Search For Exploration Works
}

\footnotetext{
Journal Website: http://usajournalshub.c om/index,php/tajas

Copyright: Original content from this work may be used under the terms of the creative commons attributes 4.0 licence.
}

\section{Z.Sh. Esanova} Doctoral Student, Karshi Engineering And Economic Institute, Faculty Of Geology And Mining, Uzbekistan

\section{ABSTRACT}

Acknowledges the importance of testing mineral deposits and it rises to the level of responsible stage of exploration and mining operations. According to the results of testing carried out important practical conclusions. Role sampling increases due to a decrease of conditions for industrial mineralization worldwide.

\section{KEYWORDS}

Determination, geological, identification, genesis, structural, morphological.

\section{INTRODUCTION}

Sampling is the process of determining the contents of useful and harmful components in ores or side rocks at many points of the deposits during prospecting, appraisal, exploration and exploitation. The need for testing minerals arose from the practice of geological exploration and mining. In ancient times, along with the introduction of mining, practical knowledge was accumulated on the testing of faces. Stone, bronze and copper wedges, chisels, hammers, crucibles, smelting forges found in the faces and at the sites of ancient mines in Central Asia, the Urals, Transbaikalia indicate their use for sampling and testing ores. Testing is a very important and responsible process of work in exploration and mining organizations. According to M.N. 
Albov [4], it is carried out to solve the following problems:

- Determination of average grades and average thicknesses of ore bodies for the purpose of calculating mineral reserves;

- Establishing the contours of ore bodies that do not have visible geological boundaries;

- Determination of correlation dependences between the contents of metals in ore, between useful and harmful components;

- Control of the accuracy of analyzes of the chemical laboratory when determining the content of components in ores;

- Determination of losses and dilution during operation;

- Drawing up plans for the extraction of ore and its useful components;

- Identification of regularities in the spatial distribution of natural types of ores, requiring the use of various technological schemes of mining, the establishment of primary and secondary zoning of deposits, conditions for the localization of ore pillars in ore bodies with their qualitative and quantitative characteristics;

- Operational management of mining operations during the operation of ore bodies without clear geological boundaries, as well as during separate excavation of different types of ores.

- Determination of mutual settlements between the mining enterprise and the consumer of the mined ore according to the data of commercial testing.

Sampling of mineral deposits is an important and crucial stage in geological exploration and mining. Like all geological science in general, sampling arose from the practical needs of geological forecasting, prospecting, prospecting and mining operations. Problems of rational sampling of various mineral deposits, which have long attracted the attention of geologists, have been studied since the beginning of the 2oth century. During this period, the scientific foundations of sampling were developed by the works of G.O. Checott, V.Ya. Glazkovsky, N.V. Baryshev, D.A. Zenkov, K.L. Pozharitsky, P.L. Kallistov and other geologists and significance, far ahead of the techniques and principles of testing.

Sampling is carried out at all stages of the study of mineral resources: geological forecasting, prospecting, mining and technological processing of ores. During exploration work, sampling reveals the potential for the integrated use of mineral raw materials in the national economy. It takes into account and ensures the identification of their morphology, the nature of the distribution of useful components in ore deposits. A correctly adopted sampling system, carried out at a number of deposits, makes it possible to accurately determine the geometric position of ore bodies in space, outline the volumes of inter-ore areas, and delineate the grade of ores. The economic value of sampling is determined by the correct identification of the average contents of useful components in the area or deposit and thereby by its reliable economic assessment. For a number of minerals, a change in content within hundredths and thousandths of a percent determines the fate of the studied deposit, especially in the current market economy conditions.

Sampling of deposits is of great importance for the delineation of ore deposits and the organization of ore mining, and, consequently, for the economy of production of the consuming industry. The economic value of sampling is determined by the reliability of the delineation of ore bodies; it is the main means of combating losses and dilution of ores during mining. Losses lead to irrecoverable loss of useful components in the depths, and dilution is often accompanied by a decrease in the yield of concentrate.

In the modern period, in a market economy, sampling controls and directs geological 
forecasting, prospecting, mining and technological processes. The study and theoretical substantiation of the impact of sampling on the economics of the mining industry is of great help to both geologists prospectors and operators - miners.

\section{MATERIALS AND METHODS}

Professor M.N. Albov is considered one of the founders of the theoretical foundations of testing. His work "Testing of Mineral Deposits" was republished from 1943 to 1975 . Five times. It outlines sampling issues in the form of a practical guide for exploration geologists, mine geologists and a textbook for students in educational institutions. The latest edition includes the issues of sampling of almost all types of minerals in their search, exploration and exploitation [1975].

Testing studies were carried out within the walls of large institutes: TsNIGRI, VITR, VIRG, VNIIYAG, VIMS (Moscow), LGI (St. Petersburg), SGI (Sverdlovsk), Kaz.IMS, Kaz.VITR (Almaty), SAIGIMS - SE "NIIMR »(Tashkent) and other institutions of the CIS countries.

The list of scientists who have devoted themselves to the study of various issues of testing for many years is quite large: M.N.Albov, N.V.Baryshev, V.I.Biryukov, V.V.Bogatsky, G.Guber, R.Richard, P.L.Kallistov, A.K.Boldyrev, V.G. Soloviev, Yu.N. Trushkov, L.I.Shimansky, V.I.Krasnikov, N.K.Razumovsky, K.S.Klyuchikhin, E.A.Rytsk, E.O.Pogrebitsky, N.V.Ivanov, D.A.Zenkov, V.M.Kreiter, V.V. Pomerantsev, A.P. Prokofiev and many others.

In the process of studying complex and diverse in geological structure, genesis, structural and morphological type of ore bodies of deposits of various types of minerals in Uzbekistan and neighboring countries during their search, exploration, production, theoretical and methodological issues of sampling were developed. S.A.Denisov, I.D.Chumakov, A.K.Polyakov, P.A.Shekhtman,
A.A.Abdumadzhitov, V.P.Fedorchuk, V.I.Smirnov, K.O.Osmonbetov, V.N.Balashov, G.I.Malmatin, V.A.Stavinsky, Mursalimov, Yu.P.Rudenko, R.V.Tsoi, D.A.Kalinichev, G.A.Buzlov, G.A.Tilyaeva, G.Ya.Kharabara, L.A.Khmelevskaya, M.U.Isokov, L.A.Khamroev, A.E.Egamberdiev, M.K.Karabaev, F.Kh.Agisheva, S.D.Bachurin, V.A.Korolev, V.N.Smirnov, T.D.Arkhipkina, A.N.Volodin, G.M.Zaletova, Sh.A.Yusupov, E.M.Zak and others.

Sampling of mineral deposits is carried out from the very initial stages of geological study of regions, districts, fields, industrial deposits to their complete development and technological processing of ores.

Sampling by stages and stages of studying mineral deposits are distinguished: - during geological forecasting works; prospecting and exploration, mining (mining) and technological processing of ores;

- on mechanization of sampling and rationalization of sample processing schemes; according to the sampling method, the following are distinguished: groove point, scoring, bulk, core-sludge, sludge, etc.

Sample handling and reduction is a complex and multi-step process. It is advisable to outline the main directions for the further development of sampling during exploration and mining operations:

- Theoretical justification of lightweight mechanized sampling methods and reduction of the initial sample weight;

- Through the use of newly created hightech instruments and equipment, as well as the development of related sciences physics and chemistry, to revive mineralogical and geophysical sampling, which makes it possible to reliably calculate mineral reserves.

Back in 1960-1970, scientists and researchers of the Department of Mine Geology of the Central 
Asian Research Institute of Geology and Mineral Raw Materials (SAIGIMS) are now the State Enterprise "NIIMR" together with specialists - geologists of geological exploration expeditions of the former Ministry of Geology and Mineral Resources of the USSR, mine geologists of large mining and metallurgical enterprises For a long period of time, the Ministry of Nonferrous Metallurgy of the USSR carried out experimental research on a large scale to develop the theory and methodology of geophysical methods for testing ore deposits. Based on the results of these research and production and technical works, devices and equipment were created and tested with the aim of widespread introduction of advanced geophysical express sampling methods at all stages of prospecting and mining operations. The developed instruments made it possible to determine the density of ore and waste rock by the method of scattered gamma radiation. The new technique made it possible to quickly distinguish and separate waste rock from ore deposits and to establish the content of useful components in mineralized bodies by means of a scattered gamma study. It has become widespread in practice in many mining regions of Central Asia and other CIS countries. Information and research results are given in the works of V.Ya. Zimalina and others [5-7], MU Isokov and others [8-9] and Kh.A. Akbarov and others [13]. Scientists, researchers, doctoral students and undergraduates in conducting research on the testing of ore deposits can use and be guided by the results of these studies.

The breadth and depth of the world of testing mineral deposits is immeasurably great. To achieve the deep roots of such a broad and important direction of geology-sampling, it is necessary to unite specialists and scientists of geologists, miners, processing technologists, economists, physicists, chemists, mathematicians, scientists of other specialties and to unite under one roof creating a special research Institute or Center according to the method and technique of testing.

Based on the testing results, important practical and theoretical conclusions are drawn. Some geologists-scientists, superficially assessing the possibilities of sampling, classify it as a secondary side research that has only applied value. History shows that only in the CIS countries there are hundreds of famous scientists-geologists who have reached high peaks of geological science, developing only one or two areas of testing, conducting experimental and other types of research work in mineral deposits in various regions of Uzbekistan, Central Asia, Kazakhstan, the Urals, The Caucasus, the Far East and other regions of the CIS.

\section{RESULT AND DISCUSSION}

One of the priority areas of work in the geological and mining industries, especially in the current conditions, when the fund of rich mineral deposits emerging to the surface is practically exhausted by the development of other branches of science - physics, chemistry, mathematics, and taking into account the general trend of decreasing conditions for industrial ores and the need for reliable and effective delineation of ore deposits and host rocks, the role of sampling processes increases sharply and, accordingly, their volume increases. Therefore, the volume of prospecting and exploration and, consequently, sampling work is increasing even more in connection with the involvement in the development of poor, but large in volume deposits, which are characterized by the absence of clear geological boundaries, ore bodies. The use of poor ores, large deposits is becoming a trend of the time in all countries of the world due to the gradual depletion of reserves of rich mineral deposits.

Highly efficient, cost-effective innovative technologies are being developed for open pit mining using high-performance methods of 
mechanization and automation of ore mining. The use of poor ores from large deposits is becoming a trend of the time in all countries of the world due to the gradual depletion of reserves of rich mineral deposits.

In the current market conditions of the economy, one of the most important directions in the development of the geological and mining industries is the use of new technologies, the search for effective methods of forecasting, prospecting and exploration of deposits and the integrated use of ores in order to increase the country's raw material base and increase the profitability of the geological and mining industries. Naturally, the integrated use of ores will lead to an increase in the volume and improvement of the quality of research on the testing of useful and harmful components at the deposits.

When transferring ore objects to an investor for geological exploration, including operation, one cannot do without high-quality research on the reliability of ore sampling. Research on the representativeness and reliability of sampling is one of the priority areas of work in the geological and mining industries, especially when the fund of rich mineral deposits coming to the surface is practically exhausted. In connection with these circumstances, under current conditions, workers in the geological and mining industries will have to conduct prospecting and exploration and mining operations on low-grade ores in terms of quality, in these conditions the role and significance of the sampling process and the reliability of its results increases dramatically.

\section{CONCLUSIONS}

In view of the continuous growth in the consumption of mineral raw materials by the industry, it is necessary to expand geological forecasting, prospecting and exploration work and the discovery of new mineral deposits. This causes an urgent need to improve the existing and develop new sampling methods in order to assess the quality and quantity of ores by applying the principle of "numbers and worlds". Anticipating these circumstances, scientists, managers and specialists of the geological and mining industries must take measures in advance, i.e. to expand the scope of work on testing, to create and strengthen scientific departments for testing with appropriate personnel, instruments, equipment, to develop and apply new methods and technologies. Teams of research institutes, faculty of laboratories of specialized specialties of departments of universities, sectoral research institutes and special structural units of geological exploration organizations in various mines

It is extremely important at the present time to unite and expand laboratories and testing sectors into large departments or Research and Production Testing Centers at research institutes and universities of a specialized direction with a large amount of budgetary allocations, equipped with first-class technology, independent premises and subsidiary enterprises, transport, equipment, instruments and computer equipment. The staffing of scientific divisions of sectors and laboratories, sampling departments or research and production centers for testing with personnel should be carried out on a competitive basis with the involvement of specialists with extensive experience in exploration and mining enterprises. The departments should unite like-minded specialists from different areas of geological exploration and mining, who are determined to develop new complex sampling technologies. These works should be financed from budgetary funds.

\section{REFERENCES}

1. Akbarov Kh.A., Holland A.L. To the methodology for defining the concept and accounting for hurricane samples during the exploitation of some mineral deposits 
in Central Asia // Proceedings of SAIGIMS. Tashkent. 1964.S. 217-223. Table 3. Il. -1. Bibl. -4 names.

2. Akbarov Kh.A., Zeman Ya.N., Spitsyn V.M. Methods for analyzing the content of metals in drill cuttings in mine conditions // Non-ferrous metallurgy. 1962. No. 4. S. 1011.

3. Akbarov Kh.A., Zeman Ya.N., Spitsyn V.M. Methods of gamma-gamma express determination of the metal content in the cuttings of a percussion drilling well at a polymetallic mine // Scientific notes of SAIGIMS. Tashkent. 1962. Issue 8. S. 101106.

4. Albov M.N. Testing of mineral deposits. M., "Nedra", 1975, 238 p.

5. Zimalina V.Ya. Reliability of exploration of ore deposits in Central Asia with uneven distribution of mineralization. Tashkent. Fan. $1992.216 \mathrm{~s}$.

6. Zimalina V.Ya., Isokov M.U., Rustamov A.A. Review of studies on the representativeness and reliability of sampling (SAIGIMS - SE "NIIMR", 19572014). Tashkent. Publishing house of SE "NIIMR", 2014. -90 p.

7. Zimalina V.Ya., Nehoda N.I., Tillyaeva G.S. Reliability of exploration for mercuryantimony deposits of a concordant type. Tashkent. Fan. $1981.216 \mathrm{~s}$.

8. Isokov M.U., Zimalina V.Ya., Tillyaeva G.S. Experience in geological study and assessment of reserves on the example of the Kokpatas gold deposit. Tashkent. RISO SE "NIIMR". 2014.110 s.

9. Isokov M.U., Zimalina V.Ya., Koloskova S.M. Conditions for placing gold mineralization, methodology and reliability of exploration on the example of the Guzhumsay deposit. Tashkent.RISO SE "NIIMR", 2013. -186 p. 